\title{
Erratum to: Ultrastructural characterization of giant endosomes induced by GTPase-deficient Rab5
}

\author{
Catherine Sem Wegner $\cdot$ Lene Malerød $\cdot$ Nina Marie Pedersen • \\ Cinzia Progida $\cdot$ Oddmund Bakke $\cdot$ Harald Stenmark $\cdot$ Andreas Brech
}

Published online: 14 November 2009

(C) Springer-Verlag 2009

Erratum to: Histochem Cell Biol

DOI 10.1007/s00418-009-0643-8

Unfortunately, two of the author's names were misspelled in the online published article.

The correct names are Catherine Sem Wegner instead of Catherine Sem Wegener and Cinzia Progida instead of Cinzia Prodiga.

The online version of the original article can be found under doi:10.1007/s00418-009-0643-8.

C. S. Wegner - L. Malerød - N. M. Pedersen - H. Stenmark ·

A. Brech $(\bowtie)$

Department of Biochemistry, Institute for Cancer Research,

The Norwegian Radium Hospital, Oslo University Hospital, Montebello, 0310 Oslo, Norway

e-mail: andreas.brech@rr-research.no; abrech@rr-research.no

C. S. Wegner - L. Malerød - N. M. Pedersen - H. Stenmark ·

A. Brech

Centre for Cancer Biomedicine, Faculty of Medicine,

University of Oslo, Montebello, 0310 Oslo, Norway

L. Malerød · H. Stenmark

Cancer Stem Cell Innovation Center, The Norwegian Radium

Hospital, Montebello, 0310 Oslo, Norway

C. Progida $\cdot$ O. Bakke

Department of Molecular Biosciences, University of Oslo, 1041,

Blindernveien 31, 0316 Oslo, Norway 